\title{
Determination of serum 25-hydroxyvitamin $D$ status among population in southern China by a high accuracy LC-MS/MS method traced to reference measurement procedure
}

Zhiliang Cai ${ }^{1,2+}$ (D), Qiaoxuan Zhang ${ }^{1,2+}$, Ziqiang Xia ${ }^{1,2}$, Songbai Zheng ${ }^{3}$, Lilan Zeng ${ }^{3}$, Liqiao Han ${ }^{1}$, Jun Yan ${ }^{1}$, Peifeng $\mathrm{Ke}^{1}$, Junhua Zhuang ${ }^{1}$, Xinzhong $\mathrm{Wu}^{1 *}$ and Xianzhang Huang ${ }^{1 *}$

\begin{abstract}
Objective: We aimed to describe the 25-hydroxyvitamin $\mathrm{D}(25(\mathrm{OH}) \mathrm{D})$ status of southern Chinese individuals by a high-accuracy liquid chromatography tandem mass spectrometry (LC-MS/MS) method which can trace to reference measurement procedure.

Materials and methods: From January 2018 to June 2019, a total of 4775 southern Chinese individuals were evaluated in our study. The serum levels of parathyroid hormone (PTH) were detected simultaneously in 162 cases. 25(OH)D was determined by LC-MS/MS, and PTH was detected using routine automated analysers. The distribution of the concentration, prevalence and seasonal variability of $25(\mathrm{OH}) \mathrm{D}$ in males and females of different age groups were studied.

Results: The mean 25(OH)D concentration in our study was $32.57 \mathrm{ng} / \mathrm{mL}(4.20-101.40 \mathrm{ng} / \mathrm{mL})$. The global 25(OH)D concentration in males was higher than that in females of different age group. The prevalence of vitamin $D$ deficiency $(<20 \mathrm{ng} / \mathrm{mL})$ in females $(16.65 \%)$ was higher than that in males $(6.83 \%)$. The prevalence of vitamin $D$ deficiency $(<20 \mathrm{ng} / \mathrm{mL}$ ) was most common in winter (22.98\% of all women and $15.49 \%$ of all men). $25(\mathrm{OH}) \mathrm{D}$ concentrations were higher in those from whom blood samples were collected in summer and autumn than in winter and spring. $25(\mathrm{OH}) \mathrm{D}_{2}$ was detected in 672 serum samples (14.07\%). In addition, there was a negative correlation between the concentrations of $25(\mathrm{OH}) \mathrm{D}$ and serum PTH $(r=-0.149, P<0.05)$.

Conclusion: Our study demonstrated that the average serum $25(\mathrm{OH}) \mathrm{D}$ concentration in southern Chinese individuals was higher than that in other Chinese cohorts by a high-accuracy LC-MS/MS method. The global $25(\mathrm{OH}) \mathrm{D}$ concentration in males was higher than that in females of different ages, and the prevalence of vitamin $\mathrm{D}$ deficiency in females was higher than that in males. Seasonal change was an important aspect of $25(\mathrm{OH}) \mathrm{D}$ concentration in young and middle-aged people but became less relevant for that in older subjects. $25(\mathrm{OH}) \mathrm{D}_{2}$ detection was of minor practical significance in our study. In addition, we also found that there was a negative correlation between the serum levels of 25(OH)D and PTH in southern Chinese individuals.
\end{abstract}

Keywords: 25-hydroxyvitamin D, LC-MS/MS, PTH

\footnotetext{
*Correspondence: wuxinzhong5054@163.com; huangxz020@163.com

${ }^{\dagger}$ Zhiliang Cai and Qiaoxuan Zhang contributed equally to this work.

'Department of Laboratory Medicine, The Second Affiliated Hospital of

Guangzhou University of Chinese Medicine, Guangzhou, China

Full list of author information is available at the end of the article
}

(c) The Author(s). 2020, corrected publication 2021. Open Access This article is distributed under the terms of the Creative Commons Attribution 4.0 International License (http://creativecommons.org/licenses/by/4.0/), which permits unrestricted use, distribution, and reproduction in any medium, provided you give appropriate credit to the original author(s) and the source, provide a link to the Creative Commons license, and indicate if changes were made. The Creative Commons Public Domain Dedication waiver (http://creativecommons.org/publicdomain/zero/1.0/) applies to the data made available in this article, unless otherwise stated. 


\section{Introduction}

Vitamin D is considered to be a class of steroid hormones, and the most important members of its family are 25hydroxyvitamin $\mathrm{D}_{3}\left(25(\mathrm{OH}) \mathrm{D}_{3}\right)$ and 25-hydroxyvitamin $\mathrm{D}_{2}\left(25(\mathrm{OH}) \mathrm{D}_{2}\right)$. In addition, $25(\mathrm{OH}) \mathrm{D}_{3}$ and $25(\mathrm{OH}) \mathrm{D}_{2}$ are the active forms of vitamin $\mathrm{D}$ [1]. $25(\mathrm{OH}) \mathrm{D}_{3}$ is mainly produced in the skin through the transformation of 7 dehydrocholesterol by UV light. $25(\mathrm{OH}) \mathrm{D}_{2}$ is primarily from plant and fungal sources [2]. Vitamin D plays a primary physiological role in maintaining the stability of serum calcium concentrations and bone health in the human body [3]. However, several studies have shown that there is a high prevalence of vitamin D deficiency in many countries around the world [4,5]. Ming-Jse Lee et al. reported that $22.4 \%$ of the northern Taiwan population had a vitamin D deficiency [6]. Akhtar et al. concluded that vitamin $\mathrm{D}$ deficiency was highly prevalent among the South Asian population, including that of India, Pakistan, Bangladesh and Sri Lanka [7]. Silvia Giulianil found that approximately $30 \%$ of the population had a deficient $25(\mathrm{OH}) \mathrm{D}$ concentration in a large Southern European population [8]. Reports on the vitamin D status in Chinese populations come from Hong Kong, Taiwan and northeastern China populations $[6,9,10]$, but there are few studies on the current status of vitamin D in South Chinese individuals, who have a different diet, lifestyle and climate than those of northeastern China populations.

Several factors may affect the production of vitamin D in the skin, including ageing, gender, geographical location, season, race, outdoor activities and so on [11]. Vitamin D deficiency may be a risk factor for secondary hyperparathyroidism, rickets, fragility fractures, cancer, diabetes and cardiovascular disease $[5,12,13]$. Many studies have reported that vitamin $\mathrm{D}$ deficiency may be more pervasive than previously thought and has become a public health problem around the world $[12,14]$. Therefore, awareness of the high prevalence of vitamin D deficiency has increased, which arouses an vigorous demand for $25(\mathrm{OH}) \mathrm{D}$ detection.

The increasing demands for $25(\mathrm{OH}) \mathrm{D}$ testing have forced clinical laboratories to develop accurate methods that are suitable for routine measurements. At present, the main detection methods of $25(\mathrm{OH}) \mathrm{D}$ are performed with a variety of techniques based on different measurement principles, which are high-performance liquid chromatography-ultraviolet detection (HPLC-UV), liquid chromatography-tandem mass spectrometry (LC-MS/ MS), and various immunoassay methods [15, 16]. Immunoassay methods include radioimmunoassay (RIA), enzyme-linked immunosorbent assay (ELISA), chemiluminescence immunoassay (CLIA), electrochemiluminescence immunoassay (ECLIA), automatic biochemical analysis and so on. Recently and in many studies, the most commonly used analytical methods to measure $25(\mathrm{OH}) \mathrm{D}$ metabolites have been based on immunoassays
[4]. However, immunoassays are largely limited by crossreactivity of antibodies and molecular receptor recognition of the $\mathrm{D}_{2}$ and $\mathrm{D}_{3}$ forms of the $25(\mathrm{OH})$ metabolite. In contrast, the high resolution of chromatography lends its sufficient detection specificity [17]. LC-MS/MS inherently has higher sensitivity and higher recoveries than those of immunoassays and is considered to be the gold standard for vitamin D detection $[16,18]$. However, although LC-MS/MS is considered to be highly specific, the accuracy of mass spectrometry detection can be affected by the analysis of isobaric compounds [19]. The best known isobaric interference of $25(\mathrm{OH}) \mathrm{D}_{3}$ is its $\mathrm{C}-3$ structural analogue 3 -epi-25(OH) $\mathrm{D}_{3}$, which can be found in large quantities of circulating [20] but does not have all the biological activities of $25(\mathrm{OH}) \mathrm{D}_{3}$. In our study, we optimized a mass spectrometric method for the detection of 3-epi-25(OH)D $3,25(\mathrm{OH}) \mathrm{D}_{3}$, 3-epi-25(OH) $\mathrm{D}_{2}$ and $25(\mathrm{OH}) \mathrm{D}_{2}$ that meets the recommended reference measurement procedure (RMP) specifications for $25(\mathrm{OH}) \mathrm{D}$ metabolites to achieve optimal authenticity and precision [21]. In addition, compared with other reference measurement procedures, the response time of the optimized mass spectrometry method for the detection of $25(\mathrm{OH}) \mathrm{D}$ is shorter than that of other RMPs [21].

The objective of our study was to evaluate the serum 25-hydroxyvitamin D status among populations in southern China by a high-accuracy LC-MS/MS method which can trace to reference measurement procedure requirements. Moreover, we studied the distribution of serum $25(\mathrm{OH}) \mathrm{D}$ concentrations in males and females of different age groups and the seasonal variability. In addition, we explored the relationship between the concentrations of serum 25(OH)D and parathyroid hormone $(\mathrm{PTH})$ in this study.

\section{Materials and methods \\ Patients}

Four thousand seven hundred and seventy-five southern Chinese individuals were evaluated in our study from January 2018 to June 2019. Fasting blood samples were taken from each subject between 8:00 a.m. and 11:00 a.m. The serum samples were federally measured at the Guangdong Provincial Hospital of Chinese Medicine and Guangzhou Huayin Medical Laboratory Center. These data were collected on the same day as the patient serum samples were collected. The study was approved by the Ethics Committee of Guangdong Provincial Hospital of Chinese Medicine, China.

\section{Reagents and instruments}

$25(\mathrm{OH}) \mathrm{D}_{3}$ and $25(\mathrm{OH}) \mathrm{D}_{2}$ reference standards were purchased from Sigma-Aldrich (St. Louis, MO, USA). Reference standards were used for the calibration of $25(\mathrm{OH}) \mathrm{D}_{2}$ and $25(\mathrm{OH}) \mathrm{D}_{3} .25(\mathrm{OH}) \mathrm{D}$ calibration solutions, standard 
reference material (SRM) $972 \mathrm{a}\left(25(\mathrm{OH}) \mathrm{D}_{2}\right.$ and $25(\mathrm{OH}) \mathrm{D}_{3}$, solvent-based) and SRM 972a (four levels, serum-based) were manufactured by the National Institute of Standards Technology (NIST) (Gaithersburg, MD, USA) and purchased from Haochu Biotechnology Co. Ltd. (Beijing, China). $25(\mathrm{OH}) \mathrm{D}_{3}-23,24,25,26,27-{ }^{13} \mathrm{C}_{5}$ (99 atom $\left.\%{ }^{13} \mathrm{C}\right)$ with a purity of $98.0 \%$ and $25(\mathrm{OH}) \mathrm{D}_{2}-6,19,19-\mathrm{d}_{3}(99$ atom $\%{ }^{13} \mathrm{C}$ ) with a purity of $99.3 \%$ were used as the internal standards (ISs) and were obtained from Sigma-Aldrich Co. (St. Louis, MO, USA). Vitamin $\mathrm{D}_{2}$, vitamin $\mathrm{D}_{3}, 1 \alpha, 25$ dihydroxyvitamin $\mathrm{D}_{3}$, 3-epi-25-hydroxyvitamin $\mathrm{D}_{3}$, 3-epi25-hydroxyvitamin $\mathrm{D}_{2},(24 \mathrm{R})$-24,25-dihydroxyvitamin $\mathrm{D}_{3}$, (24S)-24,25-dihydroxyvitamin $\mathrm{D}_{3}, 1 \alpha, 25$-dihydroxyvitamin $\mathrm{D}_{2}$, and formic acid (FA) were also purchased from this company. Acetonitrile, methanol and n-hexane (LC-MS grade) were obtained from Merck (Darmstadt, Germany). Anhydrous ethanol (HPLC grade) was purchased from Fisher (USA). $\mathrm{ZnSO}_{4} \cdot 7 \mathrm{H}_{2} \mathrm{O}$ was acquired from APIS (Beijing, China). Charcoal-stripped human serum was obtained from Bioresource Technology (FL, USA). An F5 column [kinetex F5, $2.6 \mu \mathrm{m}, 100 \mathrm{~mm} \times 2.1 \mathrm{~mm}$ (i.d.)] was obtained from Phenomenex (USA). Human serum samples were from in vitro diagnostic companies having a cooperation agreement with Huayin Health (Guangzhou Huayin Laboratory Center).

\section{Sample preparation}

First, $200 \mu \mathrm{L}$ standard solution or serum sample was placed in a $15 \mathrm{~mL}$ centrifuge tube, and $10 \mu \mathrm{L}$ internal standard solution was added to the centrifuge tube, which was vortexed for $10 \mathrm{~s}$. Then, $200 \mu \mathrm{L} 0.2 \mathrm{mmol} / \mathrm{L}$ zinc sulfate solution and $300 \mu \mathrm{L}$ methanol were added to the centrifuge tube and vortexed for $30 \mathrm{~s}$. A portion of $1 \mathrm{~mL}$ $\mathrm{n}$-hexane was added and vortexed for $1 \mathrm{~min}$; the sample was centrifuged at $4{ }^{\circ} \mathrm{C}(4000 \mathrm{rpm})$ for $5 \mathrm{~min}$, the supernatant was transferred to a $15 \mathrm{~mL}$ centrifuge tube, it was dried with nitrogen at room temperature, and then redissolved with $200 \mu \mathrm{L}$ acetonitrile:water ( $v: v=50: 50)$. The inhouse quality control (QC) materials were produced from a mixed human serum sample and made to three different concentration levels of 25-hydroxyvitamin $\mathrm{D}$ (including $25(\mathrm{OH}) \mathrm{D}_{3}$ and $\left.25(\mathrm{OH}) \mathrm{D}_{2}\right)$ : QC-low, QC-medium, and QC-high. To determine the QC values, at least two independent measurement series were analysed three times for each operation consisting of repeated preparations of standard reference material (SRM) 972a. The concentration of the QC materials was calculated according to the standard curve of SRM 972a. The values of SRM 972a consisted of four different concentrations of 25hydroxyvitamin $\mathrm{D}$ (including $25(\mathrm{OH}) \mathrm{D}_{3}$ and $25(\mathrm{OH}) \mathrm{D}_{2}$ ) and were certified by the National Institute of Standards \& Technology using ID-LC-MS/MS RMP. The experimental protocol is described in Additional file 1.
Table 1 Conditions of Triple Quadrupole MS

\begin{tabular}{lllllll}
\hline Compound & $\begin{array}{l}\text { Average } \\
\text { mass }\end{array}$ & $\begin{array}{l}\text { Precursor ion } \\
(\mathrm{m} / \mathrm{z})\end{array}$ & $\begin{array}{l}\text { Preoduct ion } \\
(\mathrm{m} / \mathrm{z})\end{array}$ & Cone $(\mathrm{V})$ & $\mathrm{CE}(\mathrm{V})$ \\
\hline $25(\mathrm{OH}) \mathrm{VD}_{3}$ & 400.6 & 383.3 & $257.2(\mathrm{Q})$ & 25 & 15 \\
& & & $365.1(\mathrm{l})$ & 24 & 15 \\
& & & 370.1 & 26 & 15 \\
$25(\mathrm{OH}) \mathrm{VD}_{3}{ }^{-1}{ }^{13} \mathrm{C}_{5}$ & 405.6 & 388.3 & $119.4(\mathrm{Q})$ & 26 & 20 \\
$25(\mathrm{OH}) \mathrm{VD}_{2}$ & 412.7 & 395.3 & $377.3(\mathrm{I})$ & 26 & 10 \\
& & & 380.3 & 26 & 15 \\
$25(\mathrm{OH}) \mathrm{VD}_{2}-\mathrm{d}_{3}$ & 415.7 & 3983 & &
\end{tabular}

CE collision energy, $Q$ transition used for quantification, I transition used for identification

\section{Biochemical parameters}

25(OH)D measurement by LC-MS/MS was performed on a Waters Acquity UPLC ${ }^{\mathrm{m}}$ with a triple quadrupole mass detector (Xevo TQ-S) system with positive electrospray ionization (ESI). The serum PTH test was performed using routine automated analysers (Cobas 8000, obtain ISO15189 certification) according to the manufacturer's instructions.

\section{LC-MS/MS conditions}

A Waters Acquity UPLC ${ }^{\mathrm{mm}}$ with a triple quadrupole mass detector (Xevo TQ-S) system in positive electrospray ionization (ESI) mode was used for analysis. The dwell time was $52 \mathrm{~ms}$ for multiple reaction monitoring (MRM) mode. The transitions and conditions for the Waters Acquity Xevo TQ-S are listed in Table 1. The selected reaction monitoring transitions were $\mathrm{m} / \mathrm{z} 383.3 \rightarrow 365.1\left[25(\mathrm{OH}) \mathrm{D}_{3}\right], \mathrm{m} / \mathrm{z} \quad 383.3 \rightarrow$ 257.2 [3-epi-25(OH) $\left.\mathrm{D}_{3}\right], \mathrm{m} / \mathrm{z} 388.3 \rightarrow 370.1\left[25(\mathrm{OH}) \mathrm{VD}_{3}-13 \mathrm{C}_{5}\right)$ ], $\mathrm{m} / \mathrm{z} \quad 395.3 \rightarrow 119.3\left[25(\mathrm{OH}) \mathrm{D}_{2}\right], \mathrm{m} / \mathrm{z} \quad 395.3 \rightarrow 377.3[3-$ epi$\left.25(\mathrm{OH}) \mathrm{D}_{2}\right]$ and $\mathrm{m} / \mathrm{z} 398.3 \rightarrow 380.3\left[25(\mathrm{OH}) \mathrm{VD}_{2}-\mathrm{d}_{3}\right]$. The optimized instrumental settings were capillary voltage $(2.6 \mathrm{kV})$, desolvation temperature $\left(600^{\circ} \mathrm{C}\right)$, source temperature $\left(150^{\circ} \mathrm{C}\right)$, desolvation gas flow $(1200 \mathrm{~L} / \mathrm{hr})$, cone gas flow (150 L/hr), nebulizer $(7 \mathrm{bar})$ and collision gas flow $(0.14 \mathrm{~mL} /$ $\mathrm{min})$. The desolvation gas was provided by a nitrogen generator (PEAK), while the collision gas was argon. Chromatographic separation was achieved by using a Kinetex ${ }^{\circ}$ F5 column at $45^{\circ} \mathrm{C}$ with $0.1 \% \mathrm{FA}$ in water (mobile phase A) and $0.1 \%$ FA in methanol (mobile phase B) at a rate of 0.45 $\mathrm{mL} / \mathrm{min}$. Initially, the mobile phase composition was $35 \% \mathrm{~A}$ and $65 \% \mathrm{~B}$ and was maintained for $1.0 \mathrm{~min}$. Then, mobile phase B was increased to $75 \%$ from $1.0 \mathrm{~min}$ to $4.5 \mathrm{~min}$. The gradient was maintained at $75 \%$ B until $7.0 \mathrm{~min}$. Next, a high organic phase of $98 \%$ B flushed the column from 7.1 to 8.5 min. Finally, initial conditions were restored for a total run time of $10.0 \mathrm{~min}$. The temperature of the autosampler was set at $5{ }^{\circ} \mathrm{C}$, and the injection volume was $10 \mu \mathrm{L}$.

\section{Data analysis and statistical methods}

For each set of samples in this study, a typical detection series was as follows: a reagent blank (65\% methanol), a 
Table 2 Assessment of the bias of $25(\mathrm{OH}) \mathrm{D}_{3}$ detected by LC-MS/MS using NIST certified SRM-972a

\begin{tabular}{|c|c|c|c|c|c|}
\hline \multirow{2}{*}{$\begin{array}{l}\text { SRM- } \\
972 \mathrm{a} \\
25(\mathrm{OH}) \mathrm{D}_{3} \\
\end{array}$} & \multicolumn{2}{|l|}{ Certified values by NIST } & \multicolumn{3}{|l|}{ LC-MS/MS } \\
\hline & Target values (ng/mL) & Uncertainty & Detected values $(\mathrm{ng} / \mathrm{mL})$ & $\mathrm{SD}(n=3)$ & $\operatorname{Bias}(\%)$ \\
\hline Level 1 & 28.80 & 1.10 & 28.43 & 0.61 & -1.27 \\
\hline Level 2 & 18.10 & 0.40 & 18.63 & 0.34 & 2.94 \\
\hline Level 3 & 19.80 & 0.40 & 20.09 & 0.23 & 1.47 \\
\hline Level 4 & 28.40 & 0.90 & 29.77 & 0.26 & 1.25 \\
\hline
\end{tabular}

SRM standard reference material, NIST National Institute of Standards \& Technology

seven-point calibration series (with increasing concentrations), a blank sample (spiked with ISWS), quality control (QC) materials, serum samples, and another reagent blank (65\% methanol). Demographic and anthropometric statistics were expressed as the mean $\pm \mathrm{SD}$ when appropriate. Groups were formed on the basis of gender, age and season. Demographic data were analysed using descriptive statistical tests performed with SPSS software package, version 20.0, GraphPad Prism 5 and Microsoft Excel 2007 (Microsoft, Redmond, WA, USA). The correlations were analysed between two groups using the Spearman $r$ test. The difference comparisons between 2 groups were performed with the unpaired t-test. A value of $P<0.05$ was considered statistically significant.

\section{Results}

25(OH)D detection via an LC-MS/MS method that traces to reference measurement procedure

The LC-MS/MS chromatographic results of SRM 972a analysed in our study at four different concentration levels of $25(\mathrm{OH}) \mathrm{D}_{3}$ and $25(\mathrm{OH}) \mathrm{D}_{2}$ are shown in Table 2 and Table 3. The biases of the four different concentration levels (Levels 1 to 4 ) of $25(\mathrm{OH}) \mathrm{D}_{3}$ were $-1.27,2.94,1.47$, and $1.52 \%$, respectively. The bias of the four different concentration levels (Levels 1 to 4 ) of $25(\mathrm{OH}) \mathrm{D}_{2}$ were -4.17 , $4.45,-1.40 \%$, and $2.26 \%$, respectively. According to the standard curve of SRM 972a, the QC material concentration levels (Levels 1 to 3 ) of $25(\mathrm{OH}) \mathrm{D}$ are described in Table 4. These data indicated that the results of $25(\mathrm{OH}) \mathrm{D}$ detected by LC-MS/MS meet reference measurement procedure requirements. The optimized mass spectrometric method for the detection of vitamin $\mathrm{D}$ has good specificity and can selectively detect $25(\mathrm{OH}) \mathrm{D}_{3}, 3$-epi-25(OH)D
(Fig. 1a), 25(OH)D $\mathrm{D}_{2}$, and 3 -epi-25(OH)D $\mathrm{D}_{2}$ (Fig. 1b) in serum.

\section{General characteristics and serum 25(OH)D status of the evaluated cohort}

As shown in Table 5, a total of 4775 individuals from South China were included in this study. The mean age of the study population was $18.61 \pm 19.88$ years ( $1-95$ years). From all 4775 serum $25(\mathrm{OH}) \mathrm{D}$ results, the proportion from males was lower than that from females: 1946 requests (40.75\%) vs. 2829 requests (59.25\%). Serum $25(\mathrm{OH}) \mathrm{D}$ was predominantly detected in the population between 1 and 40 years of age (87.6\%). The largest age group was that of children ( $<18$ years) in this study (48.57\%). The mean 25(OH)D concentration of the study group was $32.57 \pm 11.74 \mathrm{ng} / \mathrm{mL}(4.2-101.4 \mathrm{ng} / \mathrm{mL})$.

\section{Differences in serum 25(OH)D concentration based on age and gender}

In males, the global $25(\mathrm{OH}) \mathrm{D}$ concentration was higher than in females of different ages (Table 5, median 34.26 vs. $29.40 \mathrm{ng} / \mathrm{mL}, p<0.001)$. In particular, the $25(\mathrm{OH}) \mathrm{D}$ concentration in males within age groups (< 18 years: median 35.70 vs. $34.16 \mathrm{ng} / \mathrm{mL}, p<$ 0.01 and $61-80$ years: median 30.50 vs. $27.20 \mathrm{ng} / \mathrm{mL}$, $\mathrm{p}<0.001)$ was significantly higher than that in females of the same age groups (Table 5). Figure 2 shows the frequency distribution of the total $25(\mathrm{OH}) \mathrm{D}$ results in the evaluated southern Chinese population. The classification of $25(\mathrm{OH}) \mathrm{D}$ results according to the functional categories suggested by the Endocrine Society and the proportion of $25(\mathrm{OH}) \mathrm{D}$ categories by age group is shown in Fig. 3.

Table 3 Assessment of the bias of $25(\mathrm{OH}) \mathrm{D}_{2}$ detected by LC-MS/MS using NIST certified SRM-972a

\begin{tabular}{|c|c|c|c|c|c|}
\hline \multirow{2}{*}{$\begin{array}{l}\text { SRM- } \\
972 \mathrm{a} \\
25(\mathrm{OH}) \mathrm{D}_{2} \\
\end{array}$} & \multicolumn{2}{|l|}{ Certified values by NIST } & \multicolumn{3}{|l|}{ LC-MS/MS } \\
\hline & Target values (ng/mL) & Uncertainty & Detected values (ng/mL) & $\mathrm{SD}(n=3)$ & Bias(\%) \\
\hline Level 1 & 0.50 & 0.06 & 0.48 & 0.07 & -4.17 \\
\hline Level 2 & 0.81 & 0.06 & 0.84 & 0.05 & 4.45 \\
\hline Level 3 & 12.90 & 0.30 & 12.72 & 0.26 & -1.40 \\
\hline Level 4 & 0.50 & 0.10 & 0.51 & 0.04 & 2.26 \\
\hline
\end{tabular}


Table 4 Assignment of quality control materials

\begin{tabular}{|c|c|c|c|c|}
\hline & \multicolumn{2}{|l|}{$25(\mathrm{OH}) \mathrm{D}_{3}$} & \multicolumn{2}{|l|}{$25(\mathrm{OH}) \mathrm{D}_{2}$} \\
\hline & Values $\left(\bar{x}_{i} \pm \mathrm{S}_{\mathrm{i}} \mathrm{ng} / \mathrm{mL}\right)$ & CV(\%) & Values $\left(\bar{x}_{i} \pm \mathrm{S}_{\mathrm{i}} \mathrm{ng} / \mathrm{mL}\right)$ & $\mathrm{CV}(\%)$ \\
\hline QC-low & $28.14 \pm 0.99$ & 3.52 & $0.48 \pm 0.02$ & 4.82 \\
\hline QC-medium & $34.65 \pm 1.14$ & 3.28 & $5.15 \pm 0.22$ & 4.31 \\
\hline QC-high & $44.38 \pm 1.29$ & 2.91 & $11.44 \pm 0.30$ & 2.64 \\
\hline
\end{tabular}

QC quality control, $\bar{x}_{i}$ median, $S_{i}$ standard deviation, $C V$ variable coefficient
The mean total 25(OH)D concentration was highest in males younger than 18 years and lowest in females older than 80 years (Table 5$)$. The average $25(\mathrm{OH}) \mathrm{D}$ concentration showed no clear trend between age groups in males and females. An adequate total 25(OH)D concentration $(>30 \mathrm{ng} / \mathrm{mL}$ ) was most frequently found in individuals aged $<18$ years $(61.97 \%$ of all women and $69.17 \%$ of all men, Fig. 3b-c). The prevalence of $25(\mathrm{OH}) \mathrm{D}$ deficiency $(<20 \mathrm{ng} / \mathrm{mL})$ in females $(16.65 \%)$ was higher than that in males (6.83\%) (Fig. 3a). 25(OH)D deficiency was

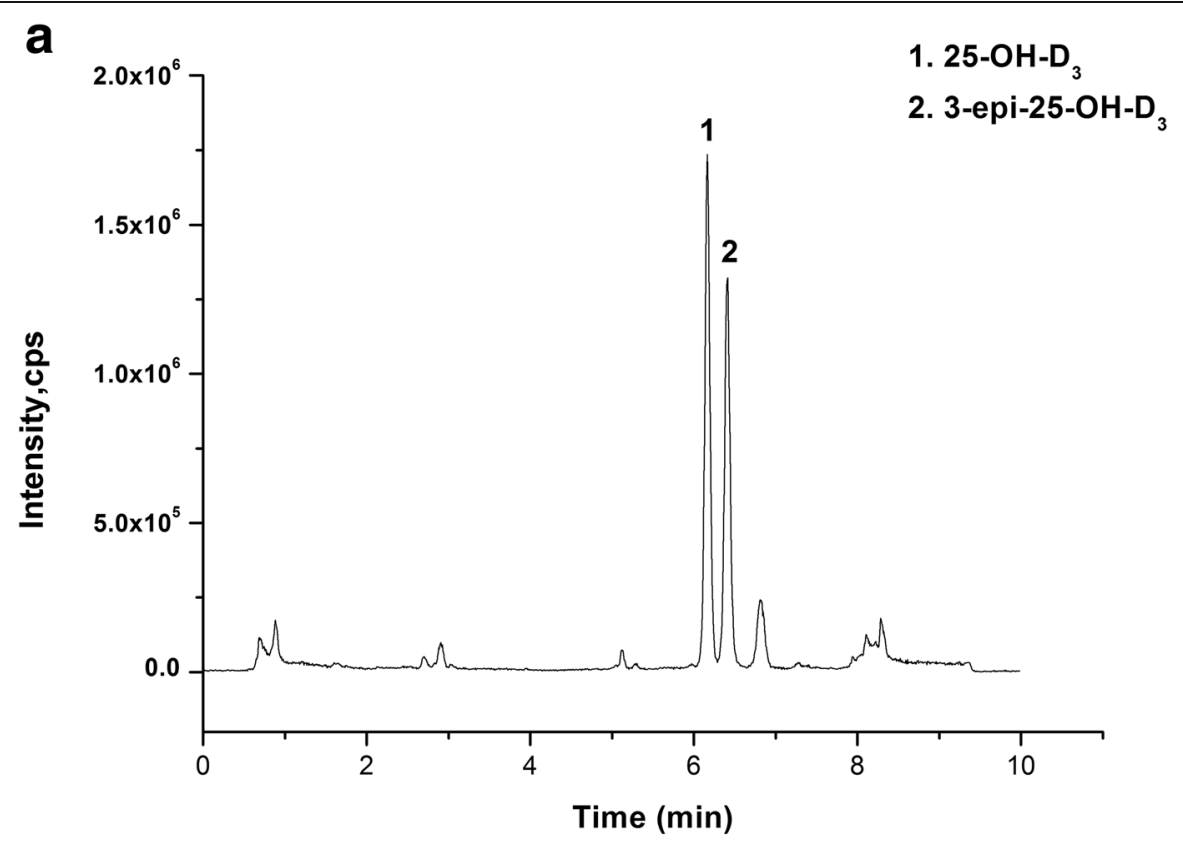

b

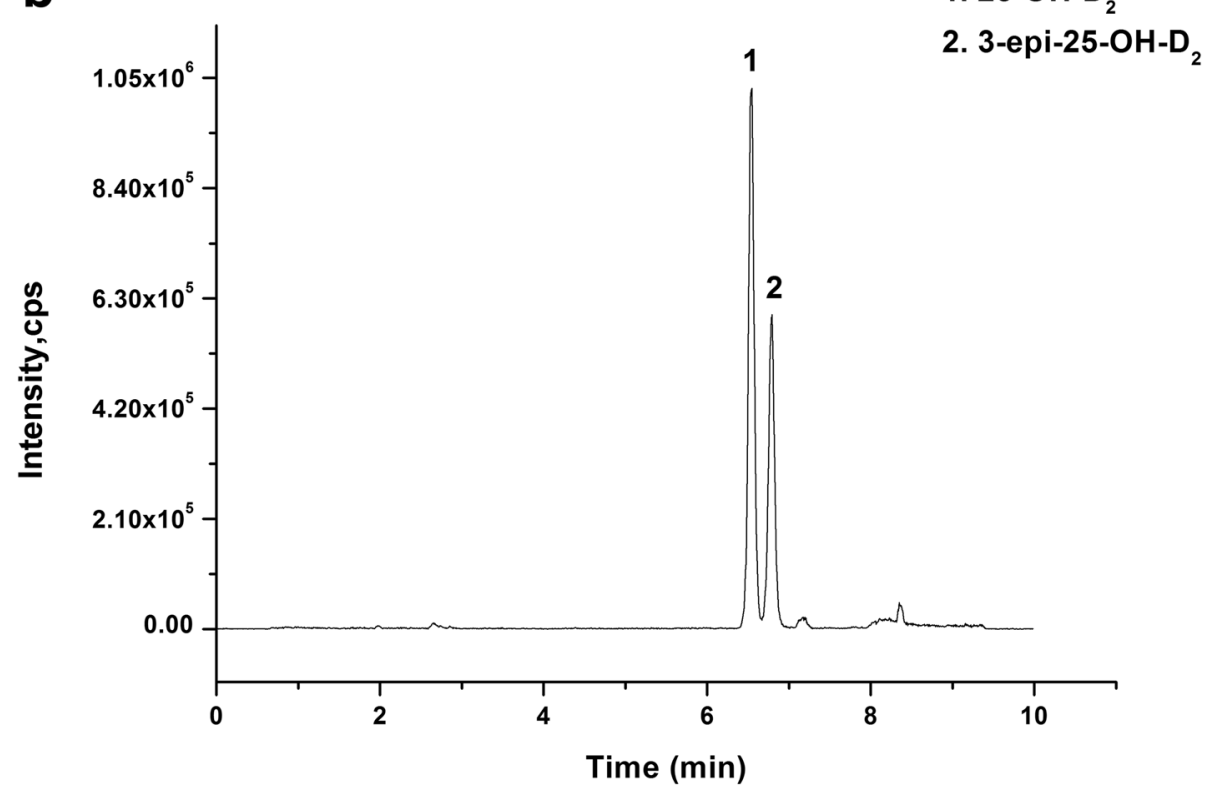

Fig. 1 Typical selected reaction monitoring chromatogram of $10 \mathrm{ng} / \mathrm{mL} 25(\mathrm{OH}) \mathrm{D}_{3}, 10 \mathrm{ng} / \mathrm{mL}$ 3-epi-25(OH) $\mathrm{D}_{3}(\mathbf{a}), 10 \mathrm{ng} / \mathrm{mL} 25(\mathrm{OH}) \mathrm{D}_{2}$ and $10 \mathrm{ng} /$ $\mathrm{mL}$ 3-epi-25(OH) $\mathrm{D}_{2}(\mathbf{b})$ in serum 
Table 5 25(OH)D concentration in 4775 serum samples from South China-descriptive statistics

\begin{tabular}{|c|c|c|c|c|c|c|c|c|c|c|c|c|}
\hline \multirow[t]{2}{*}{ Sex } & \multicolumn{2}{|l|}{ All } & \multicolumn{2}{|l|}{$<18$ years } & \multicolumn{2}{|c|}{$18-40$ years } & \multicolumn{2}{|c|}{ 41-60 years } & \multicolumn{2}{|c|}{$61-80$ years } & \multicolumn{2}{|c|}{$>80$ years } \\
\hline & $\begin{array}{l}M \\
(n=1946)\end{array}$ & $\begin{array}{l}\mathrm{F} \\
(n=2829)\end{array}$ & $\begin{array}{l}M \\
(n=1544)\end{array}$ & $\begin{array}{l}\mathrm{F} \\
(n=1165)\end{array}$ & $\begin{array}{l}M \\
(n=119)\end{array}$ & $\begin{array}{l}\mathrm{F} \\
(n=1355)\end{array}$ & $\begin{array}{l}M \\
(n=152)\end{array}$ & $\begin{array}{l}F \\
(n=166)\end{array}$ & $\begin{array}{l}M \\
(n=105)\end{array}$ & $\begin{array}{l}\mathrm{F} \\
(n=114)\end{array}$ & $\begin{array}{l}\bar{M} \\
(n=26)\end{array}$ & $\begin{array}{l}F \\
(n=29)\end{array}$ \\
\hline \multicolumn{13}{|c|}{$25(\mathrm{OH}) \mathrm{D}(\mathrm{ng} / \mathrm{mL})$} \\
\hline Median & 34.26 & $29.4^{* * *}$ & 35.7 & $34.16^{* *}$ & 26.07 & 26.43 & 29.66 & 28.29 & 30.5 & $27.2^{* * *}$ & 24.66 & 22.0 \\
\hline $\begin{array}{l}\text { Mean } \pm \\
\text { SD }\end{array}$ & $\begin{array}{l}35.45 \pm \\
11.71\end{array}$ & $\begin{array}{l}30.60 \pm \\
11.35\end{array}$ & $\begin{array}{l}37.09 \pm \\
11.58\end{array}$ & $\begin{array}{l}35.80 \pm \\
12.0\end{array}$ & $\begin{array}{l}27.86 \pm \\
9.29\end{array}$ & $\begin{array}{l}26.91 \pm \\
9.51\end{array}$ & $\begin{array}{l}29.61 \pm \\
10.65\end{array}$ & $\begin{array}{l}28.32 \pm \\
8.18\end{array}$ & $\begin{array}{l}30.65 \pm \\
6.62\end{array}$ & $\begin{array}{l}29.49 \pm \\
8.39\end{array}$ & $\begin{array}{l}26.42 \pm \\
9.0\end{array}$ & $\begin{array}{l}24.38 \pm \\
9.23\end{array}$ \\
\hline $\begin{array}{l}\text { 25th- } \\
75 \text { th }\end{array}$ & $27.2-42.0$ & $\begin{array}{l}22.67- \\
36.89\end{array}$ & $\begin{array}{l}29.2- \\
43.87\end{array}$ & $27.3-42.7$ & $\begin{array}{l}21.9- \\
34.07\end{array}$ & $\begin{array}{l}20.1- \\
32.44\end{array}$ & $\begin{array}{l}22.35- \\
37.19\end{array}$ & $\begin{array}{l}23.3- \\
32.91\end{array}$ & $\begin{array}{l}24.35- \\
37.75\end{array}$ & $\begin{array}{l}20.77- \\
31.83\end{array}$ & $\begin{array}{l}20.56- \\
31.45\end{array}$ & $\begin{array}{l}19.27- \\
28.39\end{array}$ \\
\hline
\end{tabular}

${ }^{*} P<0.05,{ }^{* *} P<0.01,{ }^{* * *} P<0.001, M$ male, $F$ female

easily observed in men of $18-40$ years of age (19.16\%) and was common in women older than 80 years of age (31.04\%) (Fig. 3b-c).

\section{Seasonal distribution of serum 25(OH)D concentrations in a South China population}

The season-specific classification of $25(\mathrm{OH}) \mathrm{D}$ results according to the functional categories suggested by the Endocrine Society in males and females is presented in Fig. 4. The prevalence of $25(\mathrm{OH}) \mathrm{D}$ deficiency $(<20 \mathrm{ng} / \mathrm{mL})$ per season was as follows: $12.83 \%$ in spring, $9.85 \%$ in summer, $11.75 \%$ in autumn, and $20.19 \%$ in winter (Fig. 4a). The prevalence of $25(\mathrm{OH}) \mathrm{D}$ deficiency $(<20 \mathrm{ng} / \mathrm{mL})$ was most common in winter $(22.98 \%$ of all women and $15.49 \%$ of all men, Fig. 4b-c). Plasma 25(OH)D concentrations were higher in subjects from whom blood samples were collected in summer and autumn than in those from whom blood samples were collected in winter and spring (Fig. 5).

The degree of seasonal variation differed with age, as shown in Fig. 6. In individuals aged 41-60 years, the maximum seasonal change in serum $25(\mathrm{OH}) \mathrm{D}$ was 8.13 $\mathrm{ng} / \mathrm{mL}$, whereas in individuals $>80$ years old, the trend was consistent (Fig. 6). The mean seasonal $25(\mathrm{OH}) \mathrm{D}$ concentration in the $<18$ years of age group was significantly higher than that in the other groups (Fig. 6). In addition, the mean total $25(\mathrm{OH}) \mathrm{D}$ concentration was highest in summer in the different age groups (Fig. 6). The relationship between weather change and the 25(OH)D level in the evaluated South China population is shown in Table 6.

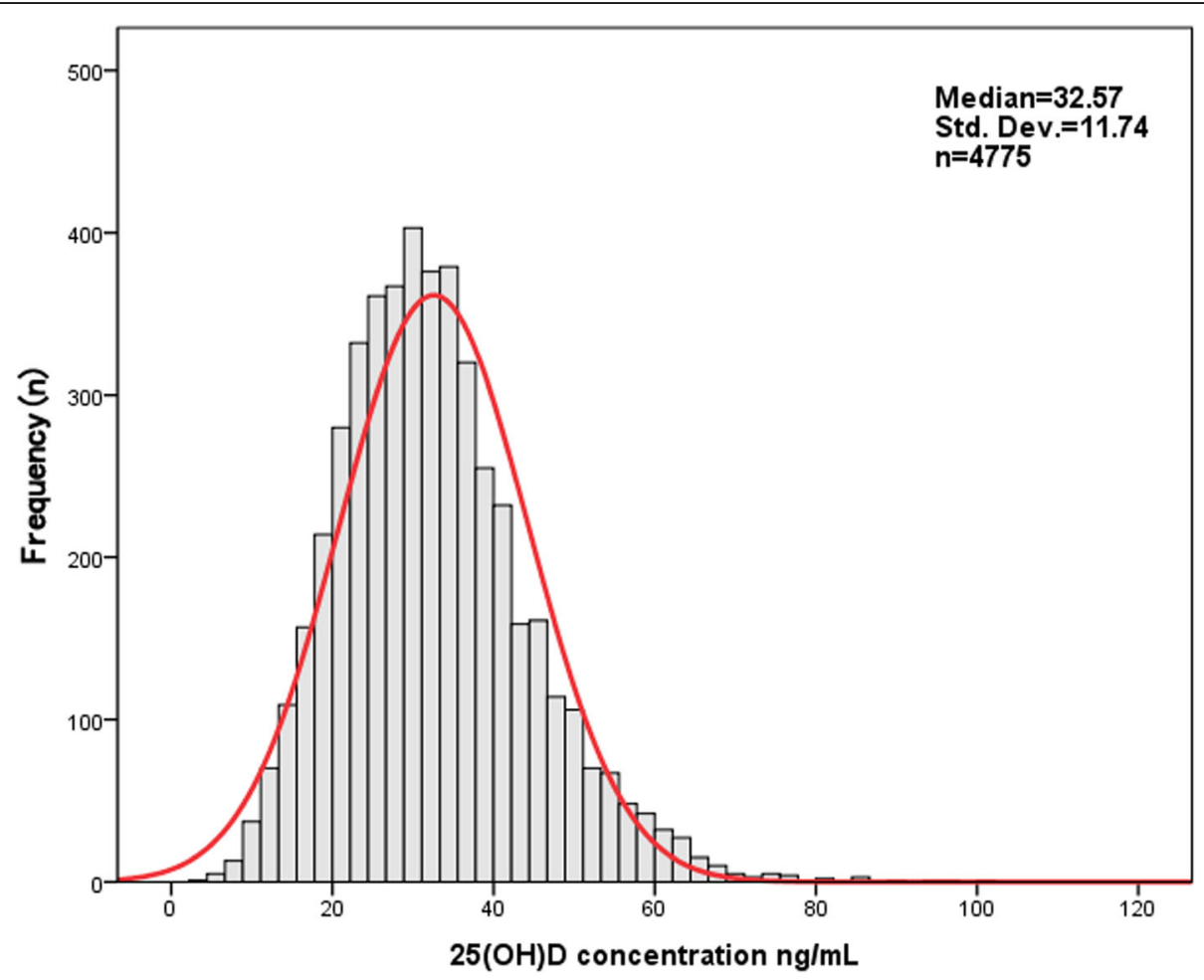

Fig. 2 Frequency distribution of serum $25(\mathrm{OH}) \mathrm{D}$ concentrations in a southern Chinese population 

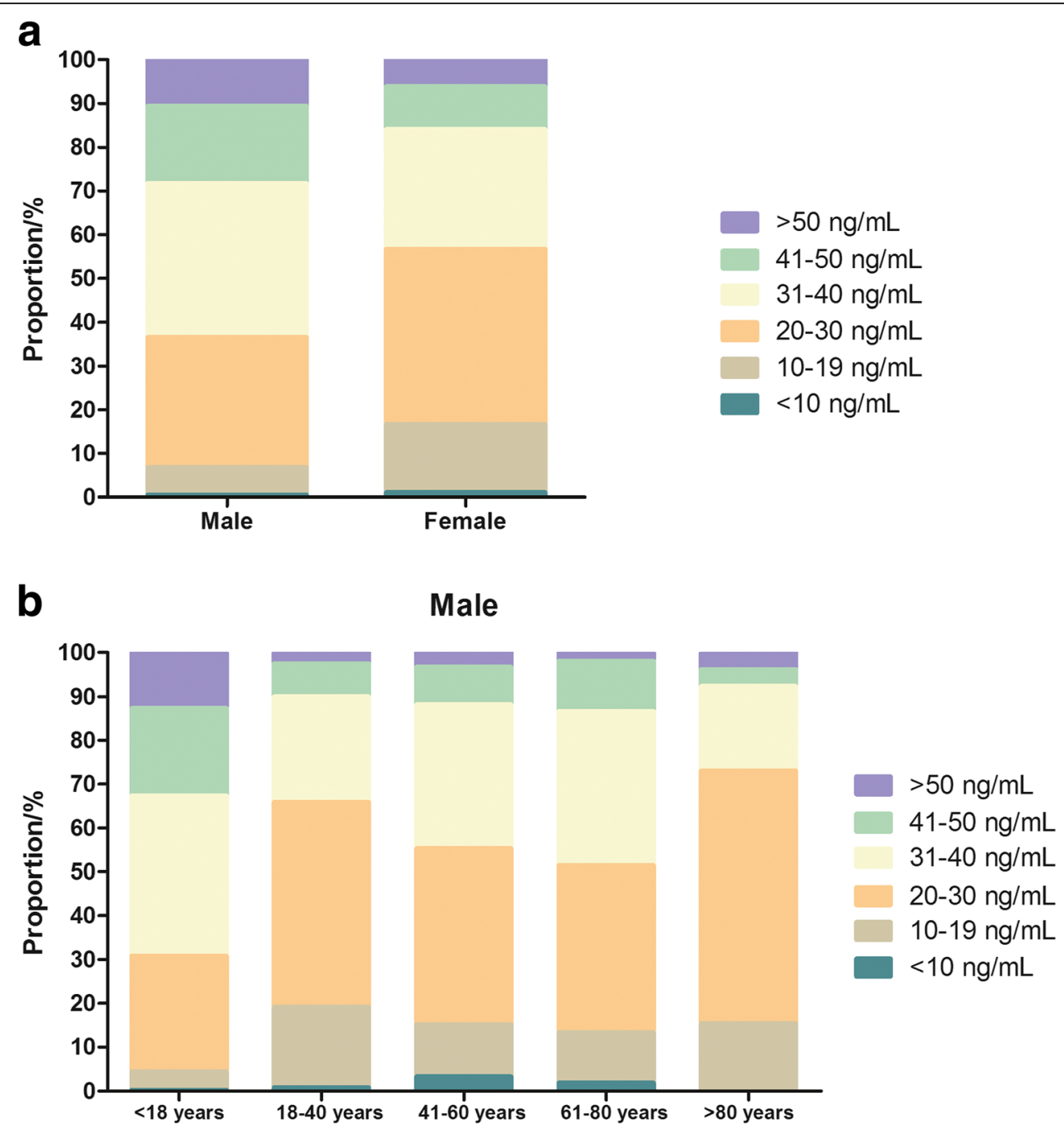

C

Female

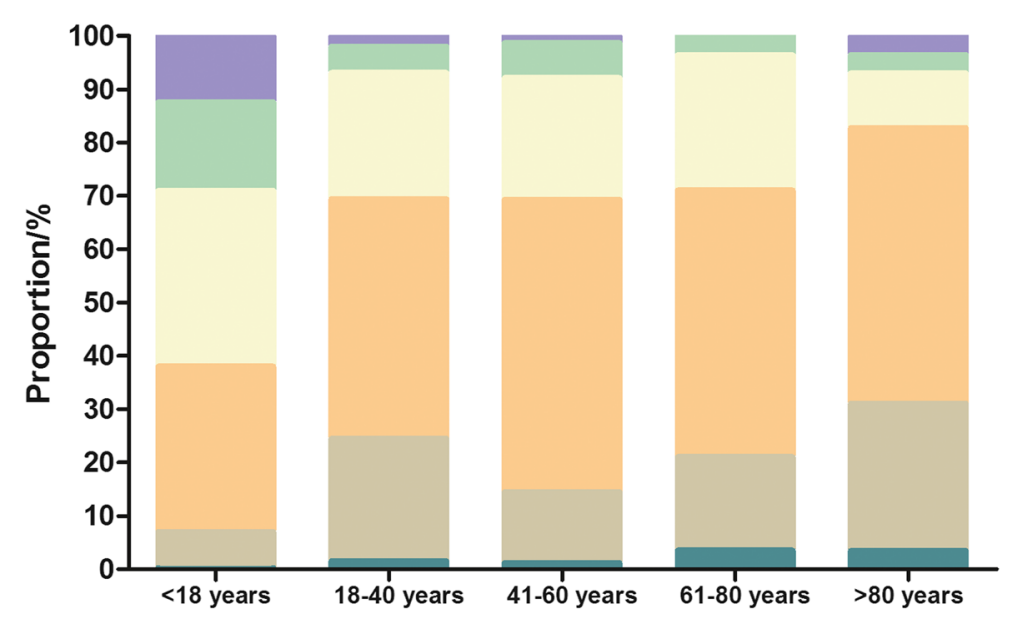

$>50 \mathrm{ng} / \mathrm{mL}$

$41-50 \mathrm{ng} / \mathrm{mL}$

$31-40 \mathrm{ng} / \mathrm{mL}$

20-30 ng/mL

$10-19 \mathrm{ng} / \mathrm{mL}$

$<10 \mathrm{ng} / \mathrm{mL}$

Fig. 3 Distribution of serum 25(OH)D concentrations in all case (a), males (b) and females (c) of different age groups according to the categories recommended by the guidelines of the Endocrine Society 

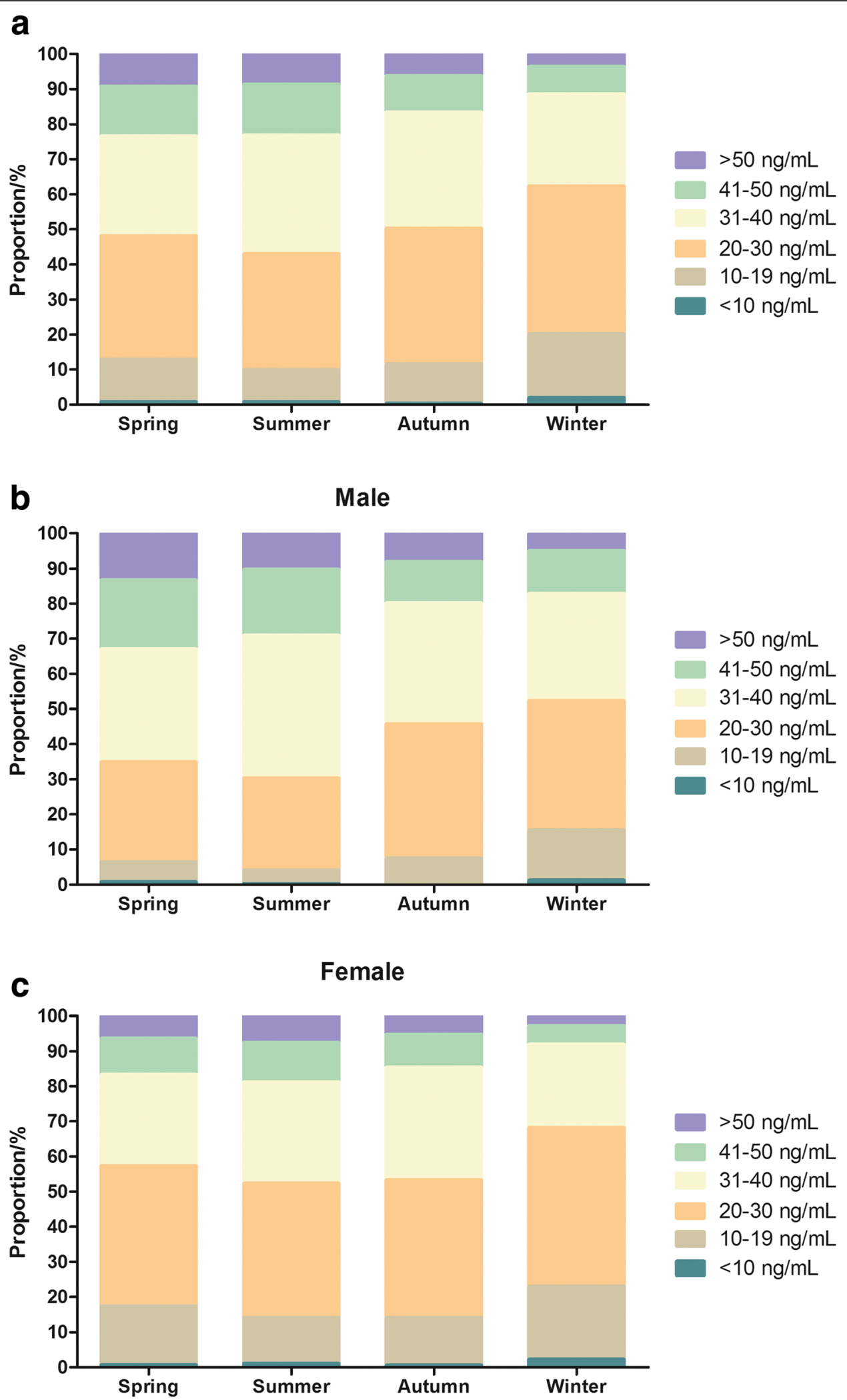

Fig. 4 Seasonal distribution of serum 25(OH)D concentrations in all case (a), males (b) and females (c) according to the categories recommended by the guidelines of the Endocrine Society 


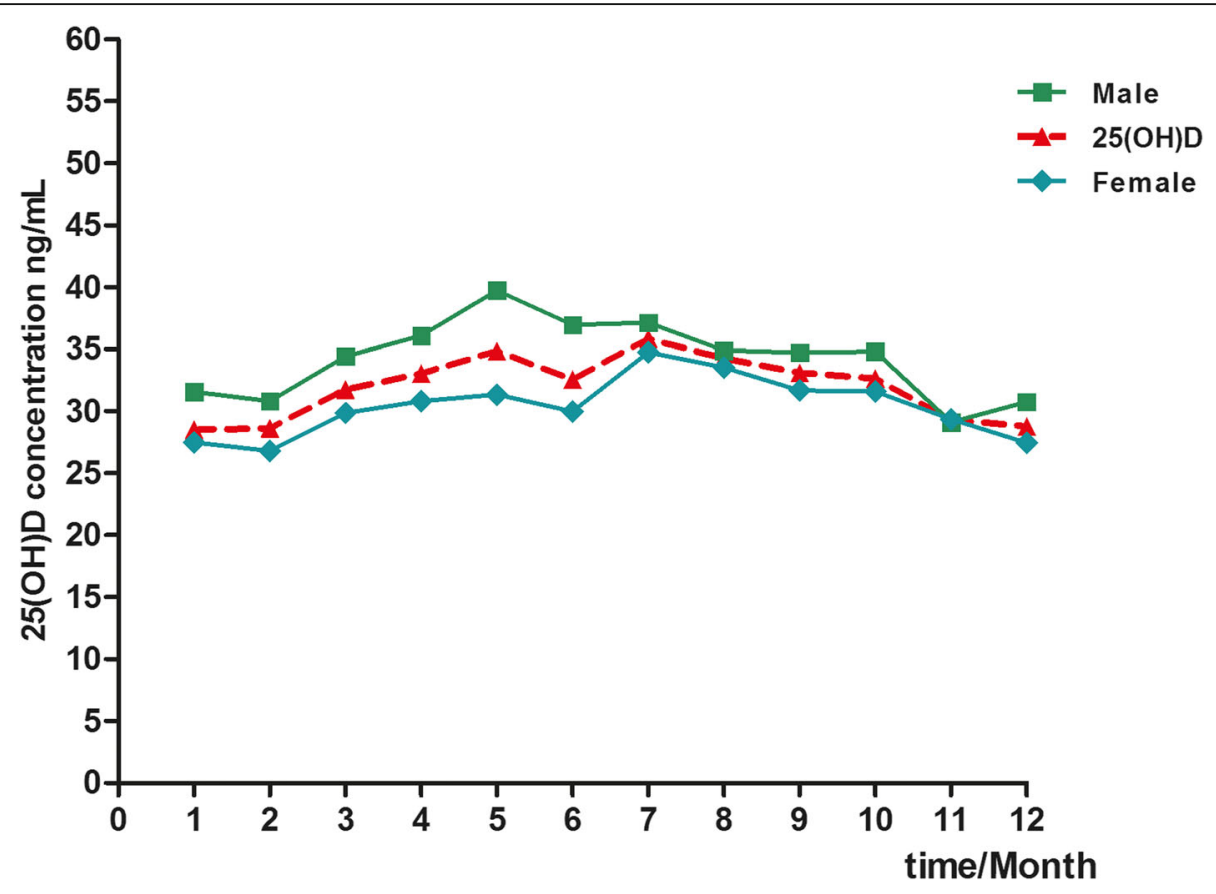

Fig. 5 Distribution of serum 25(OH)D concentrations in cases, males and females during different seasons

Prevalence of serum $25(\mathrm{OH}) \mathrm{D}_{2}$ in the evaluated population of South China

$25(\mathrm{OH}) \mathrm{D}_{2}$ was detected in quantifiable concentrations by LC-MS/MS in 672 samples. This accounts for $14.07 \%$ of the entire study. $25(\mathrm{OH}) \mathrm{D}_{2}$ was found most frequently in the < 18 years group. The average $25(\mathrm{OH}) \mathrm{D}_{2}$ concentration in males and females was 9.41 and $7.93 \mathrm{ng} / \mathrm{mL}$, respectively $(P<0.01$, Table 7$)$.
The correlation between concentrations of serum 25(OH)D and PTH

As shown in Table 8, we collected 162 samples with requested PTH detection from 4775 samples on the same occasion. The mean serum $25(\mathrm{OH}) \mathrm{D}$ concentration of the PTH-detected groups was lower than that of the entire cohort (Table 8. male: median 29.51 vs. $34.26 \mathrm{ng} /$ $\mathrm{mL}$, female: median 25.95 vs. $29.40 \mathrm{ng} / \mathrm{mL}$ ). The PTH

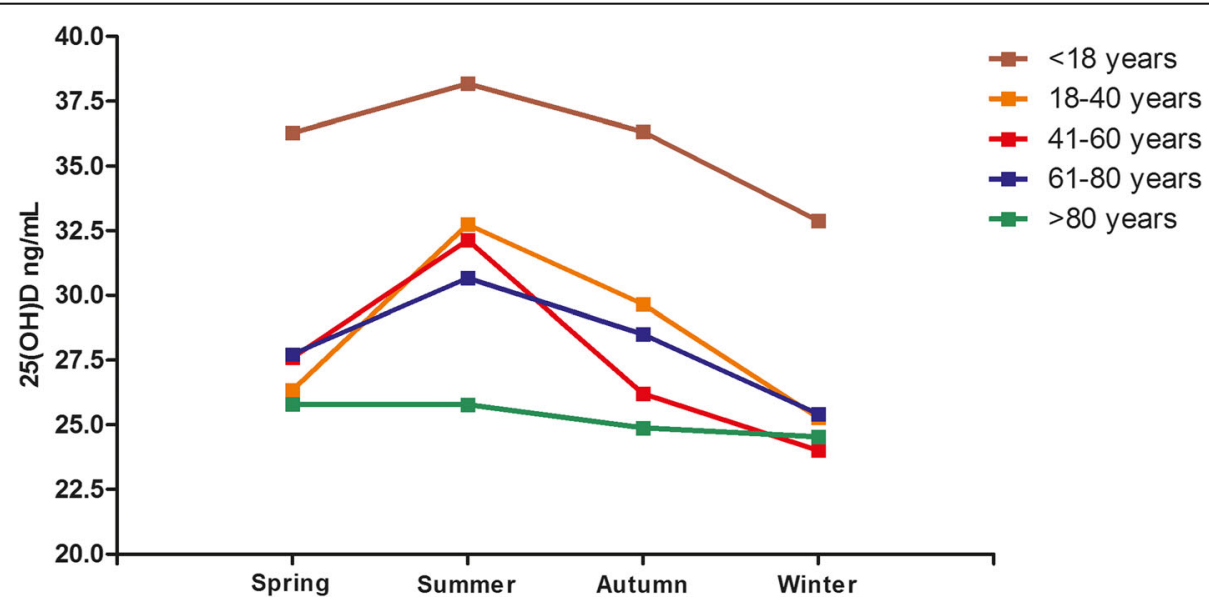

Fig. 6 Seasonal variation of mean total serum 25(OH)D concentrations in different age groups 
Table 6 The relationship between weather change and 25(OH)D levels in a population from South China

\begin{tabular}{|c|c|c|c|c|c|c|c|c|c|c|c|c|}
\hline \multirow[t]{2}{*}{$25(\mathrm{OH}) \mathrm{D}(\mathrm{ng} / \mathrm{mL})$} & \multicolumn{3}{|l|}{ Spring } & \multicolumn{3}{|c|}{ Summer } & \multicolumn{3}{|l|}{ Autumn } & \multicolumn{3}{|l|}{ Winter } \\
\hline & $\overline{M a r c h}$ & April & May & June & July & $\overline{\text { August }}$ & September & October & November & December & January & $\overline{\text { February }}$ \\
\hline Male & $\begin{array}{l}34.43 \pm \\
11.10\end{array}$ & $\begin{array}{l}36.08 \pm \\
12.27\end{array}$ & $\begin{array}{l}39.73 \pm \\
12.28\end{array}$ & $\begin{array}{l}36.94 \pm \\
12.98\end{array}$ & $\begin{array}{l}37.12 \pm \\
9.81\end{array}$ & $\begin{array}{l}34.89 \pm \\
9.50\end{array}$ & $\begin{array}{l}34.72 \pm \\
11.12\end{array}$ & $\begin{array}{l}34.80 \pm \\
10.92\end{array}$ & $\begin{array}{l}29.10 \pm \\
14.16\end{array}$ & $\begin{array}{l}30.74 \pm \\
10.06\end{array}$ & $\begin{array}{l}31.54 \pm \\
11.79\end{array}$ & $\begin{array}{l}30.81 \pm \\
10.91\end{array}$ \\
\hline Female & $\begin{array}{l}29.85 \pm \\
10.80\end{array}$ & $\begin{array}{l}30.81 \pm \\
11.98\end{array}$ & $\begin{array}{l}31.35 \pm \\
12.39\end{array}$ & $\begin{array}{l}29.97 \pm \\
11.91\end{array}$ & $\begin{array}{l}34.74 \pm \\
10.67\end{array}$ & $\begin{array}{l}33.51 \pm \\
10.91\end{array}$ & $\begin{array}{l}31.67 \pm \\
10.81\end{array}$ & $\begin{array}{l}31.57 \pm \\
11.13\end{array}$ & $\begin{array}{l}29.36 \pm \\
9.79\end{array}$ & $\begin{array}{l}27.43 \pm \\
10.04\end{array}$ & $\begin{array}{l}27.46 \pm \\
10.36\end{array}$ & $\begin{array}{l}26.78 \pm \\
9.25\end{array}$ \\
\hline \multicolumn{13}{|l|}{ Weather (days) } \\
\hline Sunny & 11 & 9.5 & 8 & 6 & 7 & 7 & 16 & 20 & 12 & 9 & 10.5 & 9 \\
\hline Overcast & 9 & 8 & 10 & 7.5 & 8 & 9 & 5 & 4 & 8 & 12 & 10 & 11 \\
\hline Rain & 11 & 12.5 & 13 & 16.5 & 16 & 15 & 9 & 7 & 10 & 10 & 10.5 & 8 \\
\hline
\end{tabular}

concentration in males was significantly higher than that in females (Table $8, P<0.05$ ). In addition, there was a negative correlation between the concentrations of 25(OH)D and serum PTH (Fig. 7, $r=-0.149, P<0.05)$.

\section{Discussion}

Compared with other methods, the detection of serum 25(OH)D levels by LC-MS/MS showed better specificity and accuracy than those of other commonly utilized methods $[16,22]$. In our study, we optimized a mass spectrometric method that meets the recommended RMP specifications for 25(OH)D metabolites to achieve optimal authenticity and precision. The LC-MS/MS method of our laboratory had high specificity and could detect 3-epi-25(OH)D $\mathrm{D}_{3}, 25(\mathrm{OH}) \mathrm{D}_{3} 3$-epi-25(OH) $\mathrm{D}_{2}$ and $25(\mathrm{OH}) \mathrm{D}_{2}$ (Fig. 1). In addition, we evaluated the accuracy of the LC-MS/MS method by analysing SRM 972a, which showed that the relative error was within the allowable range (Tables 2 and 3). The 25(OH)D results determined by this LC-MS/MS method indicate that this method meets reference measurement procedure requirements. This study illustrated the 25(OH)D status, the prevalence of vitamin D deficiency and the correlation between concentrations of $25(\mathrm{OH}) \mathrm{D}$ and serum $\mathrm{PTH}$ in a South China population. To the best of our knowledge, this is the first study to focus on a large sample of individuals, including 4775 serum samples from South China. In our study, the mean 25(OH)D concentration of the study group was $32.57 \pm 11.74 \mathrm{ng} / \mathrm{mL}$ (4.2$101.4 \mathrm{ng} / \mathrm{mL})$. 25(OH)D was detected most frequently in children aged $<18$ years $(48.57 \%$, Table 5$)$. The high demand for $25(\mathrm{OH}) \mathrm{D}$ analysis in children may be due to increased awareness of the health problems associated with vitamin $\mathrm{D}$ deficiency and the high level of vitamins required for growth and development [23].

The mean 25(OH)D concentration $(32.57 \mathrm{ng} / \mathrm{mL})$ in this study was higher than that in individuals from northeast China $(35.70 \mathrm{nmol} / \mathrm{L}$ equal to $14.28 \mathrm{ng} / \mathrm{mL}$ ) [10]. These differences can be explained by the geographical location of the subjects, the amount of sunlight and the analytical methods used. The low concentration of $25(\mathrm{OH}) \mathrm{D}$ in individuals from northeastern China $\left(38^{\circ} \mathrm{N}-56^{\circ} \mathrm{N}\right)$ is probably due to a lack of sunlight during long, cold and dark winters. In contrast, South China is located at a latitude of $23^{\circ} \mathrm{N}-34^{\circ} \mathrm{N}$ and has adequate annual sunshine [9]. In addition, vitamin supplementation may be one of the reasons for the differences between those studies [5]. Interestingly, the mean serum $25(\mathrm{OH}) \mathrm{D}$ level $(32.57 \mathrm{ng} / \mathrm{mL})$ for our group was higher than that in Hong Kong $(28.30 \mathrm{ng} / \mathrm{mL})$ [24]. This may be because rapid industrialization has exacerbated air pollution, resulting in a reduction in daily ultraviolet exposure (Hong Kong Observatory website addresses: http://www. hko.gov.hk or http://www.weather.gov.hk). In addition, the urbanization of Hong Kong has changed people's ways of life, thereby reducing outdoor activities and sunlight exposure [25]. In other previous studies, serum $25(\mathrm{OH}) \mathrm{D}$ was determined by immunoassay techniques, and their analytical performances may be systematically different from that of the LC-MS/MS method used in our study.

The global 25(OH)D concentration in males was higher than that in females of different ages (Table 5). Feitong $\mathrm{Wu}$ et al. also found that the concentration of

Table 7 Prevalence of serum $25(\mathrm{OH}) D_{2}$ in a population form South China

\begin{tabular}{|c|c|c|c|c|c|c|c|}
\hline \multirow[t]{2}{*}{ Sex } & \multicolumn{2}{|l|}{ All } & \multirow{2}{*}{$\begin{array}{l}<18 \text { years } \\
n=359\end{array}$} & \multirow{2}{*}{$\begin{array}{l}18-40 \text { years } \\
n=230\end{array}$} & \multirow{2}{*}{$\begin{array}{l}41-60 \text { years } \\
n=32\end{array}$} & \multirow{2}{*}{$\begin{array}{l}61-80 \text { years } \\
n=38\end{array}$} & \multirow{2}{*}{$\begin{array}{l}>80 \text { years } \\
n=11\end{array}$} \\
\hline & $M(n=233)$ & $F(n=439)$ & & & & & \\
\hline \multicolumn{8}{|c|}{$25(\mathrm{OH}) \mathrm{D}_{2}(\mathrm{ng} / \mathrm{mL})$} \\
\hline Median & 6.50 & 6.06 & 7.20 & 5.67 & 4.33 & 3.15 & 7.47 \\
\hline Mean \pm SD & $9.41 \pm 7.60$ & $7.93 \pm 6.42^{* *}$ & $9.82 \pm 7.67$ & $6.84 \pm 5.08$ & $7.32 \pm 6.52$ & $5.39 \pm 4.73$ & $11.02 \pm 9.29$ \\
\hline
\end{tabular}

${ }^{*} P<0.05,{ }^{*} P<0.01, M$ male, $F$ female 
Table 8 PTH concentration in 170 serum samples from 4775 25(OH)D serum samples

\begin{tabular}{|c|c|c|c|c|c|c|c|c|}
\hline \multirow[t]{2}{*}{ Sex } & \multicolumn{2}{|l|}{ All } & \multicolumn{2}{|l|}{$18-40$ years } & \multicolumn{2}{|l|}{ 41-60 years } & \multicolumn{2}{|l|}{ 61-86 years } \\
\hline & $\mathrm{M}(n=92)$ & $\mathrm{F}(n=78)$ & $M(n=15)$ & $\mathrm{F}(n=10)$ & $\mathrm{M}(n=43)$ & $\mathrm{F}(n=20)$ & $M(n=34)$ & $F(n=48)$ \\
\hline \multicolumn{9}{|c|}{ PTH (pg/mL) } \\
\hline Median & 138.00 & $169.80^{*}$ & 98.42 & 343.10 & 136.30 & $288.85^{* * *}$ & 142.10 & 143.10 \\
\hline $\begin{array}{l}\text { Mean } \pm \\
\text { SD }\end{array}$ & $\begin{array}{l}210.43 \pm \\
243.62\end{array}$ & $\begin{array}{l}339.65 \pm \\
398.82\end{array}$ & $\begin{array}{l}290.15 \pm \\
401.12\end{array}$ & $\begin{array}{l}703.45 \pm \\
698.37\end{array}$ & $\begin{array}{l}217.67 \pm \\
237.09\end{array}$ & $\begin{array}{l}461.46 \pm \\
446.12\end{array}$ & $\begin{array}{l}166.01 \pm \\
137.40\end{array}$ & $\begin{array}{l}213.109 \pm \\
189.50\end{array}$ \\
\hline \multicolumn{9}{|c|}{$25(\mathrm{OH}) \mathrm{D}(\mathrm{ng} / \mathrm{mL})$} \\
\hline Median & 29.51 & 25.95 & 32.10 & 22.50 & 24.70 & 27.55 & 30.28 & 27.35 \\
\hline $\begin{array}{l}\text { Mean } \pm \\
\text { SD }\end{array}$ & $29.67 \pm 11.32$ & $26.86 \pm 9.85$ & $33.32 \pm 12.77$ & $24.90 \pm 11.23$ & $27.76 \pm 11.36$ & $26.87 \pm 11.21$ & $30.48 \pm 10.41$ & $27.26 \pm 9.12$ \\
\hline
\end{tabular}

${ }^{*} P<0.05,{ }^{* * *} P<0.001, M$ male, $F$ female

$25(\mathrm{OH}) \mathrm{D}$ in Chinese men was higher than that in women [26], and other studies also reported consistent results [27]. However, numerous studies showed that the $25(\mathrm{OH}) \mathrm{D}$ concentration in females was higher than that in males $[8,28]$ or that there was no gender difference in their studies $[29,30]$. These differences may be due to different lifestyles, such as the duration of outdoor activities, different working environments and trace element supplementation [5]. It can be proposed that the differences between men and women are populationspecific, and there may be no systematic differences in the $25(\mathrm{OH}) \mathrm{D}$ concentrations between genders.

According to the Endocrine Society, vitamin D deficiency is defined as a level of $25(\mathrm{OH}) \mathrm{D}$ lower than 20 $\mathrm{ng} / \mathrm{mL}(50 \mathrm{nmol} / \mathrm{L})$ [31, 32]. Vitamin D deficiency has been reported in several Asian countries in diverse study populations [5, 14, 33]. In our study, the prevalence of vitamin $\mathrm{D}$ deficiency $(<20 \mathrm{ng} / \mathrm{mL})$ in females $(16.65 \%)$ was higher than that in males (6.83\%) (Fig. 3a). Jean Woo et al. also reported a similar rate of vitamin D deficiency (18\%) among young women in Hong Kong but a higher rate of vitamin D deficiency (40\%) in those from Beijing [9]. A great number of studies have estimated that more than 20\% of U.S., Canadian and European women are vitamin D deficient [34, 35]. Some studies have shown that the general deficiency of vitamin $D$ in women was related to their hormone levels, direct sunlight exposure and skin pigmentation $[5,36]$. In addition, $25(\mathrm{OH}) \mathrm{D}$ deficiency was commonly observed in females over 80 years old (31.04\%) (Fig. 3c), which is consistent with the results of Chapuy $\mathrm{MC}$ in French women. The main causes of this may be low calcium intake, and, to a lesser degree, age-related renal insufficiency. Moreover, vitamin $\mathrm{D}$ deficiency was more common in winter than in the other seasons (Fig. 4a). Various studies have also reported that the serum vitamin $\mathrm{D}$ levels in winter and

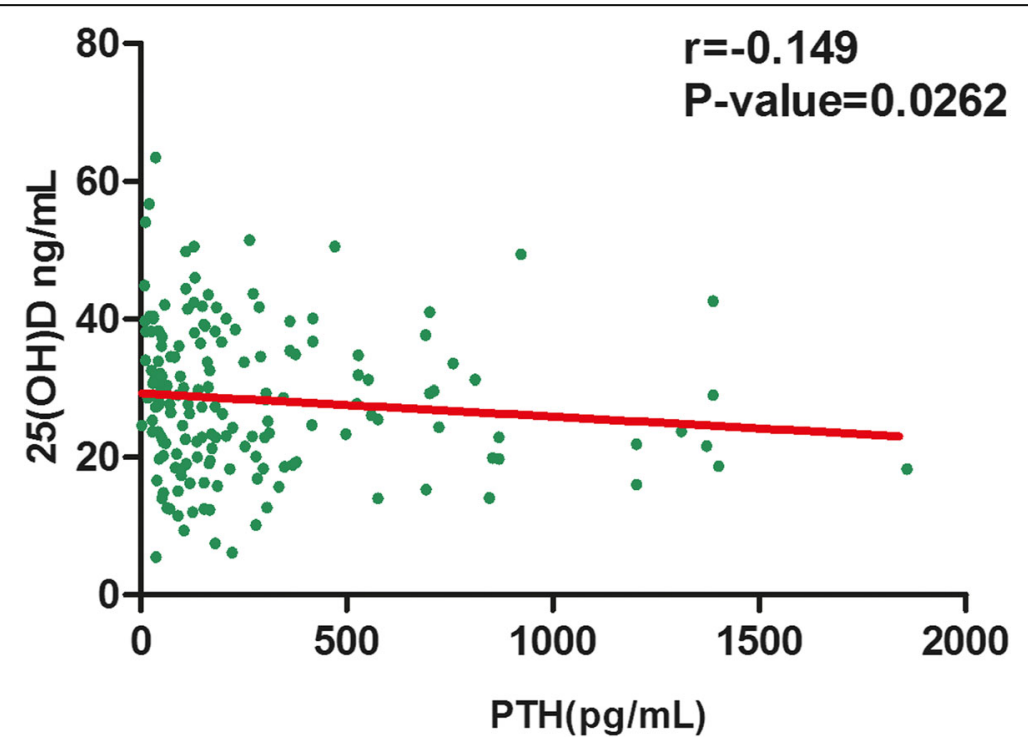

Fig. 7 The correlation between concentrations of 25(OH)D and serum PTH in 162 samples 
spring in developing countries were lower than those in summer and autumn $[5,37]$. The decrease in $25(\mathrm{OH}) \mathrm{D}$ levels in winter is mainly due to a lack of sunlight, with weaker ultraviolet radiation occurring during those months [7].

$25(\mathrm{OH}) \mathrm{D}_{2}$ is one of the main interfering substances in the immunoassay of vitamin $\mathrm{D}$ [38]. Our results showed that the prevalence of quantifiable $25(\mathrm{OH}) \mathrm{D}_{2}$ was higher in our studied population than in a study from Southern Europe [8]. In addition, the average $25(\mathrm{OH}) \mathrm{D}_{2}$ concentration was higher in males than in females (Table 7, 9.41 vs. $7.93 \mathrm{ng} / \mathrm{mL}, P<0.01)$. That may be because $25(\mathrm{OH}) \mathrm{D}_{2}$ supplements are often used [39]. Cashman et al. reported that age and vitamin $\mathrm{D}$ supplementation were positive predictors of $25(\mathrm{OH}) \mathrm{D}_{2}$ levels in serum [4]. Therefore, considering that many immunoassay methods cannot detect $25(\mathrm{OH}) \mathrm{D}_{2}$ and $25(\mathrm{OH}) \mathrm{D}_{3}$ equally, laboratories should take into account the prevalence of quantifiable concentrations of $25(\mathrm{OH}) \mathrm{D}_{2}$.

25(OH)D has an effect on bones, the intestines and kidneys, which stimulates calcium transmission from these organs to the blood. In addition, PTH can stimulate the production of $25(\mathrm{OH}) \mathrm{D}$ in the human body. A decrease in PTH depends on the negative feedback regulation of blood calcium and 25(OH)D [1]. This study indicated that there was a negative correlation between serum 25(OH)D and PTH levels (Fig. 7). Feitong Wu et al. also found that greater 25(OH)D was associated with reduced serum PTH levels in Chinese patients [26]. Other studies have shown a stronger correlation between 25(OH)D and PTH [40]. A mildly severe $25(\mathrm{OH}) \mathrm{D}$ deficiency can lead to an increase in serum $\mathrm{PTH}$, which can cause bone resorption, osteoporosis and fractures. These results indicated that $25(\mathrm{OH}) \mathrm{D}$ plays an important role in inhibiting serum $\mathrm{PTH}$, which can better protect bones.

\section{Conclusion}

In conclusion, our study demonstrated that the average serum 25(OH)D concentration in individuals from southern China is higher than that in other Chinese cohorts by a high-accuracy LC-MS/MS method, which meets reference measurement procedure requirements. The global $25(\mathrm{OH}) \mathrm{D}$ concentration in males was higher than that in females of different ages, and the prevalence of vitamin D deficiency in females was higher than that in males. Seasonal change was an important factor of $25(\mathrm{OH}) \mathrm{D}$ concentration in young and middle-aged people but became less relevant in older subjects. $25(\mathrm{OH}) \mathrm{D}_{2}$ detection was of minor practical significance in our study. In addition, we also found that there was a negative correlation between the levels of serum 25(OH)D and PTH in individuals from southern China. However, further studies are required to confirm our findings.

\section{Supplementary information}

Supplementary information accompanies this paper at https://doi.org/10. 1186/s12986-020-0427-7.

Additional file 1: Experimental protocol of SRM 972a detection.

Acknowledgements

Not applicable.

\section{Authors' contributions}

QXZ, XZW and XZH conceived and designed the experiments. ZLC and ZQX collected the data. SBZ, LLZ and ZLC conducted experiments. $\mathrm{LQH}$ and JY analysed and interpreted the data. PFK contributed reagents/materials/ analysis tools. ZLC wrote the paper, JHZ edited the paper. $\mathrm{XZH}$ provided funding. All authors read and approved the final manuscript.

\section{Funding}

Funding was obtained by the following sources: the National Key Research and Development Program of China (2019YFF0216505), the National Key Research and Development Program of China (2017YFF0205401), the Natural Science Foundation of Guangdong Province (2018A0303130124), the Specific Research Fund for TCM Science and Technology of Guangdong Provincial Hospital of Chinese Medicine (YN2016QJ15, YN2019QL01 and YN2019MJ04), as well as Guangzhou Science and Technology Project (201704020213).

Availability of data and materials

The datasets used and/or analysed during the current study are available from the corresponding author on reasonable request.

Ethics approval and consent to participate

The research involving the data of human participants is approved by Ethics Committee of Guangdong Provincial Hospital of Chinese Medicine (the other name: Second Affiliated Hospital of Guangzhou University of Chinese Medicine). The number of this Review is: ZE-2019-210.

Consent for publication

Not applicable.

\section{Competing interests}

The authors declare that they have no competing interests.

\section{Author details}

${ }^{1}$ Department of Laboratory Medicine, The Second Affiliated Hospital of Guangzhou University of Chinese Medicine, Guangzhou, China. ${ }^{2}$ Second Clinical Medical College, Guangzhou University of Chinese Medicine, Guangzhou 510120, China. ${ }^{3}$ Guangzhou Huayin Medical Laboratory Center, Guangzhou, China.

Received: 24 October 2019 Accepted: 8 January 2020 Published online: 17 January 2020

\section{References}

1. Lips P. Vitamin D physiology. Prog Biophys Mol Biol. 2006;92:4-8.

2. Lim GB. Vitamin D supplementation and CVD. Nat Rev Cardiol. 2019;16:516.

3. Johnson JA, Kumar R. Vitamin D and renal calcium transport. Curr Opin Nephrol Hypertens. 1994;3:424-9.

4. Cashman KD, Dowling KG, Skrabakova Z, Gonzalez-Gross M, Valtuena J, De Henauw S, Moreno L, Damsgaard CT, Michaelsen KF, Molgaard C, Jorde R, Grimnes G, Moschonis G, Mavrogianni C, Manios Y, Thamm M, Mensink GB, Rabenberg M, Busch MA, Cox L, Meadows S, Goldberg G, Prentice A, Dekker JM, Nijpels G, Pilz S, Swart KM, van Schoor NM, Lips P, Eiriksdottir G, Gudnason V, Cotch MF, Koskinen S, Lamberg-Allardt C, Durazo-Arvizu RA, Sempos CT, Kiely M. Vitamin D deficiency in Europe: pandemic? Am J Clin Nutr. 2016;103:1033-44.

5. Bouillon R, Norman AW, Lips P. Vitamin D deficiency. N Engl J Med. 2007; 357:1980-2.

6. Lee MJ, Hsu HJ, Wu IW, Sun CY, Ting MK, Lee CC. Vitamin D deficiency in northern Taiwan: a community-based cohort study. BMC Public Health. 2019;19:337 
7. Akhtar S. Vitamin D status in south Asian populations - risks and opportunities. Crit Rev Food Sci Nutr. 2016;56:1925-40.

8. Giuliani S, Barbieri V, Di Pierro AM, Rossi F, Widmann T, Lucchiari M, Pusceddu I, Pilz S, Obermayer-Pietsch B, Herrmann M. LC-MS/MS based 25(OH)D status in a large southern European outpatient cohort: genderand age-specific differences. Eur J Nutr. 2019;58:2511-20.

9. Woo J, Lam CWK, Leung J, Lau WY, Lau E, Ling X, Xing X, He Zhao X, Murray Skeaff C, Bacon CJ, Rockell JEP, Lambert A, Whiting SJ, Green TJ. Very high rates of vitamin $D$ insufficiency in women of child-bearing age living in Beijing and Hong Kong. Br J Nutr. 2008;99:1330-4.

10. Yan L, Prentice A, Zhang H, Wang X, Stirling DM, Golden MM. Vitamin D status and parathyroid hormone concentrations in Chinese women and men from north-east of the People's Republic of China. Eur J Clin Nutr. 2000;54:68-72.

11. Chen TC, Chimeh F, Lu Z, Mathieu J, Person KS, Zhang A, Kohn N, Martinello S, Berkowitz R, Holick MF. Factors that influence the cutaneous synthesis and dietary sources of vitamin D. Arch Biochem Biophys. 2007;460:213-7.

12. Holick MF. Vitamin D deficiency. N Engl J Med. 2007;357:266-81.

13. Giovannucci E, Liu Y, Rimm EB, Hollis BW, Fuchs CS, Stampfer MJ, Willett WC. Prospective study of predictors of vitamin D status and cancer incidence and mortality in men. J Natl Cancer Inst. 2006:98:451-9.

14. Holick MF. High prevalence of vitamin D inadequacy and implications for health. Mayo Clin Proc. 2006:81:353-73.

15. Mineva EM, Schleicher RL, Chaudhary-Webb M, Maw KL, Botelho JC, Vesper HW, Pfeiffer CM. A candidate reference measurement procedure for quantifying serum concentrations of 25-hydroxyvitamin $D(3)$ and 25 hydroxyvitamin $\mathrm{D}(2)$ using isotope-dilution liquid chromatography-tandem mass spectrometry. Anal Bioanal Chem. 2015;407:5615-24.

16. Stepman HC, Vanderroost A, Van Uytfanghe K, Thienpont LM. Candidate reference measurement procedures for serum 25-hydroxyvitamin D3 and 25-hydroxyvitamin D2 by using isotope-dilution liquid chromatographytandem mass spectrometry. Clin Chem. 2011:57:441-8.

17. Hollis BW. Editorial: the determination of circulating 25-hydroxyvitamin D: no easy task. J Clin Endocrinol Metab. 2004;89:3149-51.

18. Wallace AM, Gibson S, de la Hunty A, Lamberg-Allardt C, Ashwell M. Measurement of 25-hydroxyvitamin $D$ in the clinical laboratory: current procedures, performance characteristics and limitations. Steroids. 2010;75:477-88.

19. Mineva EM, Schleicher RL, Chaudhary-Webb M, Maw KL, Botelho JC, Vesper HW, Pfeiffer CM. A candidate reference measurement procedure for quantifying serum concentrations of 25-hydroxyvitamin D3 and 25hydroxyvitamin D2 using isotope-dilution liquid chromatography-tandem mass spectrometry. Anal Bioanal Chem. 2015;407:5615-24.

20. Singh RJ, Taylor RL, Reddy GS, Grebe SK. C-3 epimers can account for a significant proportion of total circulating 25 -hydroxyvitamin $\mathrm{D}$ in infants, complicating accurate measurement and interpretation of vitamin D status. J Clin Endocrinol Metab. 2006;91:3055-61.

21. Stockl D, Sluss PM, Thienpont LM. Specifications for trueness and precision of a reference measurement system for serum/plasma 25-hydroxyvitamin D analysis. Clin Chim Acta. 2009;408:8-13.

22. Okabe H, Shimizu C, Yamamoto M, Kikuchi R, Minami A, Chen YF, Imai H, Mizuta M, Chen Z, Chiba H, Hui SP. Determination of serum 25Hydroxyvitamin D3 by LC/MS/MS and its monthly variation in Sapporo indoor workers. Anal Sci. 2018:34:1043-7.

23. Iglesia I, Doets EL, Bel-Serrat S, Roman B, Hermoso M, Pena QL, GarciaLuzardo MR, Santana-Salquero B, Garcia-Santos Y, Vucic V, Andersen LF, Perez-Rodrigo C, Aranceta J, Cavelaars A, Decsi T, Serra-Majem L, Gurinovic M, Cetin I, Koletzko B, Moreno LA. Physiological and public health basis for assessing micronutrient requirements in children and adolescents. The EURRECA network. Matern Child Nutr. 2010;6(Suppl 2):84-99.

24. Wat WZ, Leung JY, Tam S, Kung AW. Prevalence and impact of vitamin D insufficiency in southern Chinese adults. Ann Nutr Metab. 2007;51:59-64.

25. Kung AW, Lee KK. Knowledge of vitamin D and perceptions and attitudes toward sunlight among Chinese middle-aged and elderly women: a population survey in Hong Kong. BMC Public Health. 2006;6:226.

26. Wu F, Laslett LL, Zhang Q. Threshold effects of vitamin D status on bone health in Chinese adolescents with low calcium intake. J Clin Endocrinol Metab. 2015;100:4481-9.

27. Tai SSC, Bedner M, Phinney KW. Development of a candidate reference measurement procedure for the determination of 25-Hydroxyvitamin D3 and 25-Hydroxyvitamin D2 in human serum using isotope-dilution liquid chromatography-tandem mass spectrometry. Anal Chem. 2010;82:1942-8.
28. Schleicher RL, Sternberg MR, Looker AC, Yetley EA, Lacher DA, Sempos CT Taylor CL, Durazo-Arvizu RA, Maw KL, Chaudhary-Webb M, Johnson CL, Pfeiffer CM. National estimates of serum Total 25-Hydroxyvitamin D and metabolite concentrations measured by liquid chromatography-tandem mass spectrometry in the US population during 2007-2010. J Nutr. 2016;146: 1051-61.

29. Rabenberg M, Scheidt-Nave C, Busch MA, Rieckmann N, Hintzpeter B, Mensink GB. Vitamin D status among adults in Germany--results from the German health interview and examination survey for adults (DEGS1). BMC Public Health. 2015;15:641

30. Hintzpeter B, Mensink GB, Thierfelder W, Muller MJ, Scheidt-Nave C. Vitamin D status and health correlates among German adults. Eur J Clin Nutr. 2008; 62:1079-89.

31. Bischoff-Ferrari HA, Giovannucci E, Willett WC, Dietrich T, Dawson-Hughes B. Estimation of optimal serum concentrations of 25-hydroxyvitamin D for multiple health outcomes. Am J Clin Nutr. 2006;84:18-28.

32. Holick MF, Binkley NC, Bischoff-Ferrari HA, Gordon CM, Hanley DA, Heaney RP, Murad MH, Weaver CM. Evaluation, treatment, and prevention of vitamin D deficiency: an Endocrine Society clinical practice guideline. J Clin Endocrinol Metab. 2011:96:1911-30.

33. Lips P. Vitamin D status and nutrition in Europe and Asia. J Steroid Biochem Mol Biol. 2007:103:620-5

34. Holick MF, Siris ES, Binkley N, Beard MK, Khan A, Katzer JT, Petruschke RA, Chen E, de Papp AE. Prevalence of vitamin D inadequacy among postmenopausal north American women receiving osteoporosis therapy. J Clin Endocrinol Metab. 2005:90:3215-24.

35. Greene-Finestone LS, Berger C, de Groh M, Hanley DA, Hidiroglou N, Sarafin K, Poliquin S, Krieger J, Richards JB, Goltzman D. 25-Hydroxyvitamin D in Canadian adults: biological, environmental, and behavioral correlates. Osteoporos Int. 2011;22:1389-99.

36. Islam MZ, Lamberg-Allardt C, Karkkainen M, Outila T, Salamatullah Q, Shamim AA. Vitamin D deficiency: a concern in premenopausal Bangladeshi women of two socio-economic groups in rural and urban region. Eur J Clin Nutr. 2002;56:51-6.

37. Arabi A, El-Hajj Fuleihan G, El Rassi R. Hypovitaminosis D in developing countriesprevalence, risk factors and outcomes. Nat Rev Endocrinol. 2010;6:550-61.

38. Cavalier E, Wallace AM, Carlisi A, Chapelle JP, Delanaye P, Souberbielle JC. Cross-reactivity of 25-hydroxy vitamin D2 from different commercial immunoassays for 25-hydroxy vitamin D: an evaluation without spiked samples. Clin Chem Lab Med. 2011;49:555-8.

39. Armas LA, Hollis BW, Heaney RP. Vitamin D2 is much less effective than vitamin D3 in humans. J Clin Endocrinol Metab. 2004:89:5387-91.

40. Ma MK, Mok MM, Yung S, Tang CS, Chan TM. High prevalence of vitamin D insufficiency in southern Chinese renal transplant recipients. Ren Fail. 2012; 34:980-4.

\section{Publisher's Note}

Springer Nature remains neutral with regard to jurisdictional claims in published maps and institutional affiliations.

Ready to submit your research? Choose BMC and benefit from:

- fast, convenient online submission

- thorough peer review by experienced researchers in your field

- rapid publication on acceptance

- support for research data, including large and complex data types

- gold Open Access which fosters wider collaboration and increased citations

- maximum visibility for your research: over $100 \mathrm{M}$ website views per year

At $\mathrm{BMC}$, research is always in progress.

Learn more biomedcentral.com/submission 